\title{
Country-Specific Experience, Host Country Government Corruption, And Outward Foreign Direct Investment By Korean Textile Firms
}

\author{
Kyungho Kim, Ajou University, South Korea
}

Hyunwoo Lim, Ajou University, South Korea

\begin{abstract}
This study explores how organizational learning and host country government corruption influenced outward foreign direct investment by Korean textile firms between 1986 and 1995, given that foreign direct investment decisions are not made in isolation from these two factors. The results provide empirical evidence for the recent organizational learning theory argument that the longevity of country-specific experience has a curvilinear relationship with foreign direct investment. In addition, the results suggest that the positive relationship between host country government corruption and foreign direct investment is moderated by the decreasing effect of host country-specific experience over time, suggesting that a dynamic framework of organizational learning could be used to cautiously qualify the existing bifurcated positive versus negative conclusion about the government corruption-foreign direct investment relationship.
\end{abstract}

Keywords: Outward Foreign Direct Investment; FDI; Country-Specific Experience; Government Corruption

\section{INTRODUCTION}

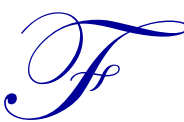

oreign direct investment (FDI) decisions cannot be made in isolation from organizational experience and host country government corruption. To examine this issue, one stream of research has explored the relationship between organizational experience and international expansion (Barkema, Bell, \& Pennings, 1996; Chang, 1995; Shaver, Mitchell, \& Yeung, 1997; Yu, 1990). Another stream of research has focused on the relationship between government corruption and FDI (Cuervo-Cazurra, 2006; Doh, Rodriguez, Uhlenbruck, Colins, \& Eden, 2003; Meschi, 2009; Rodriguez, Siegel, Hillman, \& Eden, 2006; Wei, 2000). Although the two perspectives can be complementary in a dynamic framework of organizational learning, they have been independently employed to understand FDI activities. How does organizational experience affect FDI? How is host country government corruption associated with FDI by foreign investors? Does organizational experience moderate the relationship between government corruption and FDI over time? This study sets out to answer these questions.

A multi-national enterprise (MNE) generally develops new capabilities through its experience in foreign markets (Kogut, 1983). New knowledge and capabilities gained from county-specific experience influence international expansion strategy (Barkema et al., 1996; Delios \& Beamish, 2001; Pennings, Barkema, \& Douma, 1994). Local firms have the advantage over foreign firms in their understanding of host market cultural, political, and economic institutions, but foreign firms can overcome these competitive disadvantages as they accumulate capabilities through ongoing investments in a given foreign market over time (Barkema et al., 1996; Chang, 1995; Johanson \& Vahlne, 1977). Accumulated general operations experience across countries may also determine the international expansion of MNEs (Yu, 1990).

In terms of the FDI-experience relationship, most existing studies have supported a linear relationship (Buckley \& Casson, 1981; Chang, 1995; Luo \& Peng, 1999; Yu, 1991), giving little attention to the non-linear 
relationship (Levinthal \& March, 1993; Levitt \& March, 1988; Luo \& Peng, 1999; Shaver et al., 1997). The effect of experience may decrease over time because of saturated competition, additional transaction costs, and increased production costs in a given host country (Meschi, 2009; Teece, 1986; Zhao, Kim, \& Du, 2003). Accordingly, this study explores whether outward FDI has a curvilinear relationship with accumulated country-specific experience in a given host country over time.

Government corruption varies across countries (Smarzynska \& Wei, 2000), and it forms a general rule of the game in a given country. Hence, it is necessary for foreign investors to cope with corruption in a new environment. Rodriguez et al. (2005) contend that understanding the different natures of government corruption may be fundamental to international expansion strategy and operations. The international business (IB) literature still lacks empirical evidence of the effect of government corruption on FDI activities; if anything, it rests on anecdotal evidence (Zhao et al., 2003). Moreover, existing empirical studies about the relationship between government corruption and FDI have been bifurcated: positive (Anand, Ashforth, \& Joshi, 2005; Boddewyn, 1988; Rodriguez, Uhlensruck, \& Eden, 2005; Shleifer \& Vishny, 1993) versus negative (Aidt, 2003; Heineman \& Heimann, 2006; Jain, 2001; Meschi, 2009; O’Higgins, 2006; Rodriguez et al., 2005; Wei, 2000).

This study does not explore such a mechanical bifurcated relationship. By borrowing the underlying reasoning of the dynamic organizational learning process, this study rather investigates how the relationship changes over time as a firm accumulates country-specific experience. We postulate that in the initial stage, foreign investors are likely to increase outward FDI in order to take advantage of new opportunities caused by government corruption, as the functionalist view contends (Boddewyn, 1988; Boddewyn \& Brewer, 1994). However, in the later stage, the positive relationship between FDI and government corruption will be moderated by the decreasing effect of host country-specific experience.

This study differs from the existing research on the effects of organizational learning and government corruption on FDI. To understand Korean textile firms' FDI activities, first, this study focuses on the dynamic process of organizational learning rather than the static linear perspective on the relationship between FDI and experience, suggesting a quadratic effect of experience on FDI. This study puts forward the complementary relationship between organizational learning and government corruption in understanding outward FDI activities, investigating how the relationship between outward FDI and host country government corruption is moderated by country-specific experience over time. We test the primary questions using a sample of 1,197 subsidiary-by-year cases involving Korean textile firms across 46 countries between 1986 and 1995.

The immediately following section reviews existing studies of organizational learning and government corruption and then develops the testable primary hypotheses. Thereafter, we introduce sample data and our research method. We then discuss our results and implications and suggest possible future research directions in light of the likely constraints.

\section{LITERATURE REVIEW}

\section{Experience and FDI}

Organizational learning can be defined as codified routines from history (Levitt \& March, 1988). Learning by doing is a representative source of organizational learning (Nelson \& Winter, 1982). The main tenet of organizational learning theory is that an organization learns from its past experience (Cohen \& Levinthal, 1990; Cyert \& March, 1963). How experience influences FDI has been one of the most debated questions. With respect to the role of experiential learning in the FDI context, Yu (1990) notes that country-specific and general experience significantly influence inward and outward FDI activities.

Country-specific experience is generally associated with the longevity of exposure in a given market (Barkema \& Vermeulen, 1997; Delios \& Beamish, 2001; Meschi, 2009). Firms with a longer presence in a given country are likely to have a competitive advantage over new entrants in terms of access to local resources and markets, corporate and product image (Mitchell, Shaver, \& Yeung, 1992), connections with the business community and government authorities (Luo \& Peng, 1999), and capability to reduce uncertainty in the operational and financial 
environments (Luo, 1998). New knowledge and capabilities gained from a firm's county-specific operational experience influence its international expansion strategy and subsequent performance (Barkema et al., 1996; Delios \& Beamish, 2001; Pennings et al., 1994).

A number of previous studies have also identified that general experience, such as international operations experience (Yu, 1990) and regional experience (Benito \& Gripsrud, 1992), can be easily transferred into other host countries and in turn influence the international expansion of MNEs. General organizational experience across countries is a critical predictor of multinational expansion (Luo \& Peng, 1999).

\section{Government Corruption and FDI}

Institutional environments set the rules of the game for standard economic activities within a given country (North, 1990; Rodriguez et al., 2005). Government corruption represents a fundamental institutional dimension (Kostova \& Zaheer, 1999), and it can be defined as abuse or misuse of government authority for private purposes (Meschi, 2009; Rodriguez et al., 2005; Shleifer \& Vishny, 1993). Government corruption has diverse causes such as state intervention in an economy, governmental discretionary power and monopoly (Alam, 1990), civil servant intermediation costs (Mookherjee \& Png, 1995), explicit payment of tips and speed money, and implicit favor exchanges and commissions (Zhao et al., 2003). In a country with a high level of corruption, foreign firms tend to pay bribes to government officials in order to gain favorable conditions for permits, licenses, loans, or other government services (Wei, 1997). Since corruption is often considered a social evil and it hinders standard economic activities, OECD countries have attempted to root out corruption to create a better business environment (Zhao et al., 2003).

Nonetheless, government corruption is an ongoing institutional problem across countries. It is becoming increasingly important to understand the institutional environment because an international expansion strategy cannot be determined in isolation from the host country's institutional environment. The linkage between government corruption and FDI activities has been a fundamental issue among policymakers and practitioners (Heineman \& Heimann, 2006; Henisz, 2000). In connecting government corruption with FDI activities, Mauro (1995) and Tolluock (1996) argue that government corruption is closely related to performance (Mauro, 1995). Existing studies have argued that the relationship between government corruption and FDI may be either positive (Anand, Ashforth, \& Joshi, 2005; Boddewyn, 1988; Rodriguez et al., 2005; Shleifer \& Vishny, 1993) or negative (Aidt, 2003; Heineman \& Heimann, 2006; Jain, 2001; Meschi, 2009; Rodriguez et al., 2005). These bifurcated empirical findings have increased confusion rather than contributing to theoretical and empirical implications. By applying the dynamic process of organizational learning, this study carefully qualifies the established bifurcated corruption-FDI relationship.

\section{Government Corruption in Korea, 1986-1995 (Fifth and Sixth Republic Government Periods)}

According to the 2013 Corruption Perceptions Index (CPI), South Korea scored 55 out of 100 and came in $27^{\text {th }}$ among the 34 countries belonging to the Organization for Economic Cooperation and Development (OECD), suggesting that South Korea was one of the highly corrupted countries during the fifth and sixth Republic government periods. Corporations have combatted corruption since Korea's transition from a long-time military dictatorship to democracy in 1987. However, the transition period between 1986 and 1995 saw a high level of government corruption and the economy faced a number of corporate corruption cases. Large corporations such as conglomerates and chaebols, for example, have been involved in tax evasion and corruption (Kim, 2009). Corruption still creates problems for companies in South Korea, including excessive bureaucracy, weak corporate governance, misapplication and abuse of laws and regulations, and non-transparent regulatory processes (Business Anti-Corruption Portal, 2013).

From the survey to understand the most corrupt groups of people in Korea, Kim (2009) found that politicians (70.6 percent) are the most corrupt group, with civil servants (12.2 percent) and many others following such that the bureaucratic corruption in South Korea has reached the level of a national crisis. Kim (2009) also noted that in the Fifth and Sixth Republic periods, many bureaucrats in public institutions intentionally misused and abused public funds for their own interests rather than the public interest. During these transition periods, slush fund 
scandals with chaebols, large companies, and politicians were common, worsening the government corruption problem. For example, two former presidents appeared in court as defendants in 1993: Chun Doo-hwan and Roh Tae-woo, representing the Fifth and Sixth Republic periods, respectively. In the first trial, the former was sentenced to death and fined in connection with the amassing of a 220 billion won $^{\mathrm{i}}$ slush fund, and in the second, the latter was sentenced to 22 -and-a-half years in prison and fined 283.8 billion won for bribery (Kim, 2009). These cases represent significant sources of bureaucratic corruption and contributed to discrediting South Korea.

The Fifth and Sixth Republic government periods provided an environment characterized by a high level of government corruption. While coping with the high level of government corruption in the domestic market during these two transition periods, many Korean companies accumulated general knowledge and capabilities to deal with government corruption. Hence, we postulate that Korean textile firms could apply their accumulated general knowledge when entering foreign counties with a high level of corruption.

\section{HYPOTHESES}

\section{Country-Specific Experience and FDI}

Country-specific experience generally occurs when a firm continues operations and acquires countryspecific knowledge in a foreign market over time. A firm's international expansion may rest on the acquisition of tacit knowledge through learning by doing across countries (Kogut, 1991). International expansion occurs incrementally because a firm tends to increase its commitment and take advantage of emerging opportunities in a given host country (Chang, 1995). Previous studies imply that the international expansion process is a series of incremental commitment processes in an evolutionary context.

Familiarity with a market reduces cost while increasing the possibility that a foreign firm will further serve that market through direct investment (Buckley \& Casson, 1981). Some studies have found that MNEs' next FDI decisions are positively influenced by their foreign subsidiaries' operational experiences in a given market. Ball and Tschoegl (1982), for example, found that the longer presence of a bank in a given foreign country enables foreign investors to become more familiar with the country, making them more likely to undertake additional FDI activities. Hence, according to the traditional tenet of organizational learning theory, we postulate that the more experience a firm has in a country, the greater the possibility that it will invest further in that country.

Hypothesis 1: The longevity of country-specific experience will be positively associated with the amount of foreign direct investment in a given host country.

\section{Government Corruption and FDI}

Again, political and nonmarket transactions are often essential for multinational entry and expansion when entering host countries with a high level of corruption (Rodriguez et al., 2005). Although recognizing that government corruption refers to a nonmarket constraint, many foreign investors choose to enter a host country with high corruption. Some view corruption as an opportunity for political behavior by MNEs (Anand et al., 2005; Boddewyn, 1988; Boddewyn \& Brewer, 1994; Rodriguez et al., 2005). Specifically, the functionalist view emphasizes the redeeming value of government corruption, suggesting that corruption has a positive effect on economic development (Zhao et al., 2003). This positive relationship has often been observed in Southeast Asian countries such as Indonesia and Thailand, most of which have been growing fast in spite of perceived high levels of government corruption (Tanzi, 1998). Previous studies confirm that government corruption is definitely contributing to economic growth.

General operations experience gained from both the home country and host countries can be applicable to a new host country (Yu, 1990). Delios and Beamish, (2001), for example, contend that intangible assets gained from the home country can be applied into new geographic markets without depreciating the value of such assets, implying that knowledge gained from experiential learning from the home country can be transferred to host

\footnotetext{
'Won indicates the Korean currency unit. For readers' understanding, 1 US dollar was changed 1,276 won in 2009. 
counties. The acquisition and application of experiential learning depends on a firm's "absorptive capacity" (Cohen \& Levinthal, 1990). Korean textile firms developed absorptive capacity while coping with government corruption during the two transition periods. The accumulated firm-specific knowledge of how to deal with government corruption before and during the transition periods provided a competitive force to pursue international expansion because such tacit knowledge cannot be easily gained (Inkpen \& Beamish, 1997). Hence, we assume that the outward investment of Korean textile firms is likely to increase regardless of the high level of government corruption in host countries because they tend to regard government corruption as creating opportunities.

Hypothesis 2: Host country government corruption will be positively associated with foreign direct investment in a given host country.

\section{Non-Linear Effect of Experience}

Most of the existing studies contend that organizational experience has a positive linear relationship with FDI. Contrary to the established argument, the relationship between host country experience and performance may be non-linear (Mitchell, Shaver, \& Yeung, 1994; Shaver et al., 1997). In other words, the effect of organizational experience on FDI may be strong during the early stage of international expansion process because country-specific knowledge gained in the early stage may offset the costs of operations (Zaheer, 1995). However, the positive effect of experience on performance decreases in the later stage because the number of foreign firms increases in a foreign market, overcrowding occurs, and competition becomes much more intense over time (Luo \& Peng, 1999; Mitchell et al., 1994; Shaver et al., 1997), reducing the likelihood of further investment by foreign firms over time. We accept and attempt to test this emerging argument and in turn to provide empirical evidence. Hence, we postulate that there is a curvilinear relationship between experience and the amount of foreign investment, given the decreasing effect of country-specific experience.

Hypothesis 3: The positive effect of country-specific experience on the amount of foreign direct investment will diminish as a foreign subsidiary continues operations in a host country (i.e., curvilinear relationship).

\section{Moderating Effect of Experience}

Meschi (2009) argues that "differences in country knowledge among foreign firms lead to different reactions to government corruptions" (p. 247), implying that an MNE may develop and accumulate distinct countryspecific capabilities and knowledge when continuing operations in a host country with a different level of government corruption. The functionalist perspective argues that government corruption creates favorable opportunities, which in turn lead to an increase in FDI by foreign investors. This perspective centers on the static perspective for the corruption-FDI relationship. However, as described earlier, FDI decisions are a dynamic process that evolves over time. That is, FDI decisions cannot be determined in isolation from organizational experience in a given country. Hence, the final question is to how the positive government corruption-FDI relationship in the initial stage evolves as an MNE continues operations in a host country. Specifically, this study cautiously examines how the positive corruption-FDI relationship is moderated by the country-specific experience effect, given that experiential learning in host countries tends to take place through coping with country-specific government corruption environments. Hence, we postulate that the government corruption-FDI relationship may be moderated by the decreasing effect of host country-specific experience in a given country such that the positive effect of government corruption on foreign investment observed in the early stage will decrease over time.

Hypothesis 4: The positive relationship between government corruption and the amount of foreign direct investment will be moderated by the decreasing effect of host country-specific experience.

\section{METHOD AND ANALYSIS}

\section{Sample}

This study uses a sample of 1197 subsidiary-by-year cases. Forty-six countries with different levels of government corruption, circa 1995, were host to Korean textile firms. Except for France, Germany, Japan, the 
United Kingdom, and the United States, the host countries were classified as developing countries. FDI data for Korean firms have been recorded since 1986. Between 1986 and 1995, Korean textile firms were major contributors to the improvement of national employment and production (Statistics Korea, 2004). While South Korea saw increasing labor costs during this period, labor-intensive Korean textile firms depended on FDI to explore overseas opportunities.

When designing research driven by longitudinal data, researchers tend to face the so-called censoring problem (Allison, 1984). This study set 1986 as the beginning of the observation period because, even though Korean textile firms engaged in FDI before 1986, there were few pre-1986 observations and, moreover, these were not officially documented. The year 1995 was right censored because the focus is on the early period, in which empirical studies are still scarce. Furthermore, there are missing and unavailable data for several years after 1995.

\section{Dependent Variable}

As mentioned earlier, this study is primarily interested in how outward FDI by Korean textile firms is influenced by their experience and host country government corruption. The amount of FDI has been widely used a fundamental proxy for international expansion (Buckley et al., 2007; Yu, 1990). The dependent variable is the total amount of annual FDI by Korean textile firms in a given host country.

\section{Independent Variables}

\section{Country-Specific Experience}

The longevity of country-specific experience (EXP) was measured as the accumulated number of years that a certain foreign subsidiary operated in a given host country (Chang, 1995; Erramilli, 1991). Specifically, we first identified all subsidiaries in host countries and then calculated the accumulated number of years a foreign subsidiary had in a given market as a proxy for country-specific experience. The longevity of experience in our sample ranges from 1 to 10 years.

\section{Government Corruption}

Government corruption (GCOR) can be measured by aggregating all categories of corrupt transactions into a single index (Rodriguez et al., 2005). Three types of corruption indexes are commonly used (Meschi, 2009): The Economist's Economic Intelligence Unit and Political Risk Services Group (PRS) indexes (i.e., ICRG ratings); the Global Competitiveness Report (GCR) and World Development Report (WDR) indexes; and the Transparency International indexes. These indexes are measured in slightly distinct ways. This study employs PRS ratings because only they can be applied for the observation period of this study (i.e., between 1986 and 1995). Since 1979, PRS has recorded and reported 22 variables about political, financial, and economic risks for around 162 countries, circa 2009. This study focuses only on corruption-rating scores. The original corruption score in the PRS ratings ranges between 0 (high level of corruption) and 6 (no corruption). To facilitate interpretation, the author recalculated the corruption score so that 0 means "no corruption" and 6 refers to the highest level of corruption.

\section{Control Variables}

This study controls for some confounding variables at the parent company and macro environment levels that are known to influence FDI activities.

\section{Ownership Rate}

At the parent company level, the ownership rate of the parent company for a foreign subsidiary indicates the commitment to its subsidiary. A higher level of ownership rate by a parent company means a larger commitment to its subsidiary $(\mathrm{Li}, 1995)$; therefore, a positive relationship between ownership rate and FDI is expected. 


\section{Geographic Gravity}

MNEs tend to start their foreign operations in foreign countries that are geographically, culturally, and economically similar to their home countries (Buckley et al., 2007; Yu, 1990). A large geographic distance between two countries indicates market access difficulties (Mayer \& Zignago, 2011). Hence, it is expected that longer geographic distance will have a negative relationship with FDI. The Centre d'Etudes Prospectives et d'Informations Internationales (CEPII) distance measures were used for bilateral distances.

We also control location-specific economic environments: inflation and tariff rates. High inflation rates discourage market-seeking FDI because of increased uncertainty and volatility, and they generally lead foreign investors to a cost disadvantage through domestic currency devaluation (Buckley et al., 2007). Tariff rates represent trade barriers or restraints (Hennart \& Park, 1994). Hence, we expect a negative relationship between outward FDI and host country inflation and tariff rates.

\section{Analytic Method}

Our sample consists of time-series unbalanced panel data (e.g., some firms in our sample are observed for 10 years, but others for only 5 years). Fundamental to the analysis of panel data is the choice of a coefficient estimator: pooled ordinary least squares (pooled OLS), fixed effects $(F E)$, or random effects (RE) (Baum, 2006; Cameron \& Trivedi, 2009). The $F E$ and $R E$ OLS estimations are usually preferred to pooled OLS when dealing with heterogeneity across panels and time. We used the $F E$ and $R E$ models alternatively and then applied the Hausman test, a commonly recommended post-estimation test, to investigate whether the selected method is appropriate. We found that the $F E$ model is appropriate. The final time-series $F E$ regression model is:

$\mathrm{FDI}=\alpha+\beta_{1} \mathrm{EXP}+\beta_{2} \mathrm{GCOR}-\beta_{3} \mathrm{EXP}^{2}-\beta_{4}\left(\mathrm{EXP}^{2}\right) \times(\mathrm{GCOR})+\beta_{5}$ Controls $+\varepsilon$

where FDI $=$ the amount of FDI by Korean textile firms in a given year, EXP $=$ the longevity of country-specific experience in a given year, GCOR = the host country's government corruption score in a given year, and Controls = ownership rates, geographic distance between South Korea and the host country, inflation rates, and tariff rates.

\section{RESULT}

Table 1 shows the means and standard deviations of variables and the correlations between variables. Table 1 indicates that most variables generally have very low correlations, except for the correlation between gravity distance and tariff rates. We examined the severity of multicollinearity using the variance inflation factor (VIF) test. We found that there are no general multicollinearity problems with the data, although the VIF value is 15 for inflation, which is slightly high but acceptable.

The hypotheses were examined using nested regression models to understand the model improvement. The first base model, Model 1 in Table 2, includes only control variables for subsidiary characteristics and countryspecific environments. The primary variables were added into Models 2, 3, 4, and 5 in sequence: experience effect in Model 2, host country corruption in Model 3, non-linear effect of experience on foreign investment in Model 4, and moderating effect of host country-specific experience on the relationship between government corruption and foreign investment in Model 5.

Table 1: Basic Statistics and Correlation Matrix

\begin{tabular}{cccccccccccc}
\hline & Obs. & Mean & Std. Dev. & Min & Max & $\mathbf{1}$ & $\mathbf{2}$ & $\mathbf{3}$ & $\mathbf{4}$ & $\mathbf{5}$ \\
\hline 1 & 2705 & 905.47 & 2083.87 & 2 & 51000 & 1 & & & & \\
2 & 2705 & 80.27 & 25.20 & 8 & 100 & $.1416^{*}$ & 1 & & & \\
3 & 2505 & 6.67 & 1.37 & .21 & 10 & -.0248 & $.0503^{*}$ & 1 & & \\
4 & 2705 & 5911.57 & 4940.92 & 955.65 & 18600.7 & $.0744^{*}$ & $.2502^{*}$ & $.2323^{*}$ & 1 & \\
5 & 2505 & 24.32 & 13.16 & 3.49 & 105.36 & $-.1304^{*}$ & $-.0825^{*}$ & $-.4697^{*}$ & $.7194^{*}$ & 1 & \\
6 & 2705 & 2.82 & 1.94 & 1 & 10 & $.0819^{*}$ & $.1054^{*}$ & $.1475^{*}$ & $.3466^{*}$ & $-.3670^{*}$ & 1 \\
7 & 2525 & 2.61 & 1.10 & 0 & 5.92 & $.0608^{*}$ & $.1107^{*}$ & .0059 & $.2088^{*}$ & $-.1071^{*}$ & $.0758^{*}$ \\
\hline
\end{tabular}

1: Investment Amount (Unit: 1,000 won), 2: Ownership Rate (\%), 3: Inflation Rate (\%), 4: Geographic Distance (Unit: km), 5: Tariff Rate (\%), 6: Experience, 7: Government Corruption. * $\mathrm{p}<0.05$ 
The improvement in Wald chi-square is significant at the $1 \%$ confidence level, implying that the addition of main effect variables in each nested model results in significant model improvements. Therefore, the results imply that the covariates in the models are non-trivial for the explanation of outward FDI established by Korean textile firms.

Of the control variables, ownership rate, a firm-specific variable, has an expected positive association with outward foreign investment, supporting the argument that as a parent company's ownership rate in its subsidiary increases, its commitment increases $(\mathrm{Li}, 1995)$. The high commitment of a parent company to its foreign subsidiary leads to larger investment in a host country. The result in Model 1 also shows that of host country-specific environment measures, only tariff rates have an expected negative relationship with outward foreign investment at a marginally significant level, meaning that MNEs are less likely to invest in a host country with high tariff rates.

With respect to our primary hypotheses, Hypothesis 1 predicted that the length of country-specific experience (EXP) of a foreign subsidiary would have a positive relationship with the amount of foreign investment in a given host country. The results strongly support Hypothesis 1 across all models. Hypothesis 2 predicted that host country government corruption (GCOR) would be positively associated with the amount of FDI. The results in Table 2 strongly support Hypothesis 2 across all models. For Hypothesis 3, which addresses one of the primary concerns, this study attempted to test the non-linear effect of organizational experience on FDI. The result in Model 4 shows that the coefficient of the quadratic length of experience (i.e., $\mathrm{EXP}^{2}$ ) is negative at a marginally significant level, meaning that the positive effect of host country-specific experience, as measured by the length of operations in a given host country, declines over time. In Hypothesis 4, this study predicted that the effect of government corruption on foreign investment would be moderated by the decreasing effect of country-specific experience in a given host country (i.e., a negative interaction term (-GCOR $\left.\times \mathrm{EXP}^{2}\right)$ between host country-specific experience and the level of government corruption). Consistent with the prediction, the coefficient for the interaction term in Model 5 was negative at a significant level. The result in Model 5 strongly supports the argument that the positive effect of host country corruption on foreign investment is negatively moderated by the longevity of host country-specific experience for a foreign subsidiary.

Table 2: Nested Time-Series Regression Model (Dep. Variable: Foreign Investment Amount)

\begin{tabular}{|c|c|c|c|c|c|}
\hline & Model 1 & Model 2 & Model 3 & Model 4 & Model 5 \\
\hline \multirow[t]{2}{*}{ Constant } & 35.8737 & -356.6103 & -600.2418 & $-740.8901 * * *$ & $-831.7907 * * *$ \\
\hline & $(237.01)$ & $(240.30)$ & $(263.1757)$ & $(275.4791)$ & $(278.8031)$ \\
\hline \multirow[t]{2}{*}{ Ownership Rate } & $10.14 * * *$ & $9.6906 * * *$ & $9.6517 * * *$ & $9.5073 * * *$ & $9.6746 * * *$ \\
\hline & $(1.6781)$ & $(1.6523)$ & $(1.6691)$ & $(1.6683)$ & $(1.6664)$ \\
\hline \multirow[t]{2}{*}{ Inflation } & -4.2565 & 18.2776 & 20.5025 & 29.5752 & 31.9795 \\
\hline & $(24.5228)$ & $(24.3072)$ & $(24.4169)$ & $(24.9699)$ & $(24.9785)$ \\
\hline \multirow[t]{2}{*}{ Geographic Distance } & .0176 & .0054 & .0050 & .0045 & .0058 \\
\hline & $(.0146)$ & $(.0144)$ & $(.0152)$ & $(.0151)$ & $(.0151)$ \\
\hline \multirow[t]{2}{*}{ Tariff Rate } & $-7.2001 *$ & -2.6063 & -.2661 & .3063 & .7937 \\
\hline & $(3.9060)$ & $(3.9033)$ & $(4.1561)$ & $(4.1632)$ & $(4.1611)$ \\
\hline Host Country Experience & & $\begin{array}{c}90.2104 * * * \\
(13.5483)\end{array}$ & $\begin{array}{c}98.4792 * * * \\
(14.7868)\end{array}$ & $\begin{array}{c}163.7790 * * * \\
(40.9464)\end{array}$ & $\begin{array}{c}186.0332 * * * \\
(42.4110)\end{array}$ \\
\hline Host Country Corruption & & & $\begin{array}{c}61.6917 * * \\
(30.0102)\end{array}$ & $\begin{array}{l}60.7421 * * \\
(29.9900)\end{array}$ & $\begin{array}{l}70.0446 * * \\
(30.3271)\end{array}$ \\
\hline Host Country Experience ${ }^{2}$ & & & & $\begin{array}{l}-8.1969 * \\
(4.7947)\end{array}$ & $\begin{array}{l}-3.5369 \\
(1.5227)\end{array}$ \\
\hline $\begin{array}{l}\left.\text { (Host Country Experience }^{2}\right) \\
\times \\
(\text { Host Country Corruption) }\end{array}$ & & & & & $\begin{array}{c}-3.0336 * * \\
(1.5227)\end{array}$ \\
\hline R-square & .0653 & .0871 & .0847 & .0878 & .0943 \\
\hline Wald Chi-square & $58.72 * * *$ & $105.09 * * *$ & $102.56 * * *$ & $105.68 * * *$ & $109.97 * * *$ \\
\hline No. of Obs. & 1197 & 1197 & 1172 & 1172 & 1172 \\
\hline
\end{tabular}

\section{DISCUSSION AND IMPLICATIONS}

This study applied the organizational learning theory and government corruption in order to understand and carefully qualify outward FDI by Korean textile firms between 1986 and 1995. This study set out with two primary 
research purposes to fill the gap of the existing IB research. First, this study investigated whether FDI has a nonlinear relationship with host country-specific experience, given that organizational learning occurs through an evolutionary dynamic process. Hence, this study specifically explored whether the effect of experience on foreign investment diminishes over time as an MNE accumulates host country-specific experience in a given market. Second, this study questioned the existing bifurcated negative versus positive conclusion about the effect of government corruption on FDI, assuming that existing studies ignored the complementary relationship with the dynamic process of organizational learning. Accordingly, this study investigated whether the effect of government corruption on FDI is moderated by the decreasing effect of the longevity of country-specific experience.

First, the results across all models strongly support the positive effect of country-specific experience on foreign investment, as expected in Hypothesis 1 . This result definitely provides evidence for the main tenet of the Uppsala school's international expansion process. Hence, this study suggests that MNEs benefit from their host country-specific experience, and that they are likely to increase foreign investment in order to take advantage of experiential learning in a host country.

However, the results from a careful further analysis show that the coefficient of quadratic host countryspecific experience, as expected in Hypothesis 3, is negatively associated with the amount of foreign investment in a given foreign market, meaning that the effect of experience definitely declines over time. This finding provides evidence for the argument that a firm's capabilities are continually changing and are developed through ongoing investment activities (Delios \& Beamish, 2001).

The results from Hypotheses 1 and 3 provide a theoretical contribution. This study identified two stages in which a firm's capabilities are shaped by its continuing investment experience in a given host country. FDI activities in the early stage are positively influenced by a firm's knowledge accumulated through ongoing operations in a given country. Accordingly, these results support the notion that a country-specific experience allows a firm to increase its familiarity with a host country, allowing a firm to reduce its associated liability of foreignness, in turn contributing to the economic development of the host country (Barkema \& Vermeulen, 1997).

This study, however, carefully qualifies this argument when considering the dynamic process of organizational learning, and then it confirms that a firm's capabilities evolve over time. The findings provide evidence for the theoretical argument that country-specific experience has a curvilinear relationship with FDI (Levinthal \& March, 1993; Levitt \& March, 1988; Luo \& Peng, 1999; Shaver et al., 1997). The findings suggest that the established simple linear assumption for the effect of experience on FDI should be carefully re-examined.

Given that the effect of host country-specific experience on FDI is not sustainable (i.e., non-linear), this study can provide practical implications. MNEs should implement different FDI strategies over time. In the early stage, they may focus on exploiting the benefiting effect of host country-specific experience. In the later stage, however, firms should pay more attention to exploring other strategic options, given that they cannot leverage continuously such country-specific experience. The findings suggest that the sustainability of MNEs in a host market may be determined by the development of dynamic capabilities through ambidexterity (i.e., the combination of exploitation of current capabilities and exploration of new capabilities) (Teece, Pisano, \& Shuen, 1997). An additional analysis ${ }^{\mathrm{ii}}$ found that foreign subsidiaries of Korean textile firms face a high hazard rate at the end of five years, the so-called liability of adolescence, rather than at either the early or the later stage. This additional finding also justifies the adoption of a different, sequential FDI strategy years after entering a host country.

In terms of the effect of government corruption on FDI, most existing studies have argued that the effect is either positive (Anand et al., 2005; Rodriguez et al., 2005; Shleifer \& Vishny, 1993; Boddewyn, 1988) or negative (Aidt, 2003; Heineman \& Heimann, 2006; Jain, 2001; Luo, 2004; Meschi, 2009; Rodriguez et al., 2005). The results in Models 3, 4, and 5 strongly support the positive argument, as expected in Hypothesis 2, providing empirical evidence for the argument of the functionalist view, which emphasizes the redeeming value of government corruption in that it creates opportunity (Boddewyn, 1988; Boddewyn \& Brewer, 1994; Rodriguez et al., 2005). The positive effect may also come from general operations experience gained from the home country that can be easily

\footnotetext{
ii The output was not reported here because it is not our primary concern, but it will be provided on demand.
} 
applied to host countries ( $\mathrm{Yu}, 1990)$. That is, Korean firms accumulated general knowledge while coping with government corruption in the home country during the two transition periods, and they are already equipped with the absorptive capacity to respond to and deal with prospective government corruption in host countries. Hence, Korean textile firms equipped with such absorptive capacity are likely to increase their amount of foreign investment in host countries with a high level of corruption because they regard government corruption as providing opportunities rather than being an environmental constraint.

However, this study assumed that the relationship between government corruption and FDI activities would be more complex than most prior empirical studies have concluded. The results in Model 5 show that the positive relationship between government corruption and FDI is definitely moderated by the decreasing effect of host country-specific experience in a given market, as predicted in Hypothesis 4. This result implies that the simple bifurcated corruption-FDI relationship should be cautiously interpreted, given that the corruption-driven opportunity at the early stage can be offset over time when considering the decreasing effect of country-specific experience (i.e., the dynamic framework of organizational learning). In addition, the results suggest that the moderating effect may vary across host countries because the extent to which host country-specific experience diminishes differs according to the level of government corruption in host counties.

To enhance our understanding in Model 5, we introduce two firms operating in different host countries with contrasting corruption scores and then compare how the moderating effect of country-specific experience varies between two countries: one operating in a host country with the highest PRS score (6), which indicates a "highly corrupt country," and the other in a host country with a low PRS score (1) which indicates a "relatively transparent country." The negative sign in the interaction term in Model 5 means that the positive government corruption-FDI relationship declines as a firm accumulates operational experience in a host country.

To simplify, let us take only an interaction term from Equation 1:

FDI $=-3.0336($ Government Corruption $) \times\left(\right.$ Experience $\left.^{2}\right)$.

Let us assume that the longevity of experience increases from five years to six years; firm A has operations in a host country with lower levels of corruption, and firm B has operations in a counterpart country with higher levels of corruption.

According to Model 5, the interaction terms of A and B definitely have negative slopes, suggesting that the longevity of experience does moderate the main effect of government corruption on FDI in both firms. The amount of foreign investment of firm A declines by about $43 \%$ (i.e., from -76,000 won in year 5 to $-109,000$ won in year 6 ) with one year of experience in a host country with a low level of corruption, while the amount of foreign investment of firm B declines by about $44 \%$ (i.e., from $-455,000$ won in year 5 to $-655,000$ won in year 6) with one year of experience in a counterpart country. These specific findings are interesting in two ways. The absolute reduced amount of foreign investment is definitely larger in a country with a higher level of corruption than in an antithetic country, but the ratio of reduction is almost equal. These findings suggest that the decreasing effect of accumulated country-specific experience strongly offsets the positive effect of government corruption on foreign investment over time, regardless of the level of host country corruption.

These findings provide a new perspective on the corruption-FDI relationship. The existing literature has paid more attention to the simple binary effect of government corruption. When incorporating a dynamic framework of organizational learning into the model, however, the established bifurcated effect of government corruption on FDI is no longer supported, suggesting that government corruption does not independently influence FDI. Hence, the relationship should be cautiously interpreted in the literature. These findings also provide practical implications. Given that the non-linear corruption-FDI relationship varies according to the level of corruption, managers may implement different FDI strategies over time when entering host countries with different levels of government corruption.

Like other studies, this study has some limitations. First, the sample data may not represent the whole population because foreign investments increased sharply after 1992, but the observation ended at the end of 1995 
owing to unavailable or missing data for several years between 1995 and 2001. Hence, subsidiaries entering foreign markets after 1992 were not sufficiently considered in this study. Second, this study focused on a labor-intensive industry, but future studies may examine yet-to-be types of industries facing different environmental constraints in host countries. Moreover, Korean textile firms have already experienced the maturity stage of their industry life cycle and subsequently entered the restructuring phase in their home country. In other words, Korean textile firms entered foreign countries based on the strong necessity of extending their declining domestic opportunities into international markets. Future studies can apply industries with different industry life cycle. Third, although this study admits that general experience in other countries may have an influence on outward FDI, it did not consider general experience gained from other countries in the model. Fourth, this study used only PRS scores as proxies for government corruption because they were available for the observation period, but other corruption indexes (e.g., the Global Competitive Report, the World Development Report) and subjective measures could be used to complement our one-dimensional factor. Fifth, FDI decisions can also be influenced by firm-specific characteristics such as innovation intensity, R\&D intensity, and entry timing, and the generally competitive dynamic environment in a host country. Although the importance of these factors is recognized, this study did not include these variables in the model because, unfortunately, the current sample data collected at the foreign subsidiary level do not include these variables. Future study could be enriched by the introduction of these variables into the model.

Lastly, regarding our sample data, we have to admit that our dataset is relatively old. While working on the data, we found that during the period between 1996 and 2001, three Korean government-affiliated organizations have recorded FDI-related data in turn. In this process, unfortunately data from several years were missing. Moreover, Korean government-affiliated organizations recently declared not to disclose FDI data to the public after 2007 to protect information of Korean firms. We may be able to collect data between 2002 and 2006 if we try hard. However, we are still missing data from 1996 to 2001 and the new dataset (from 2002 to 2006) would be useless. Although we admit that the dataset is relatively old, we still believe that this study can contribute to the IB literature by explaining the FDI activities of Korean firms in the early period on which few empirical studies have focused.

\section{CONCLUSION}

This study departs from the existing work in three ways. First, it provides evidence for the recent organizational learning argument that the experience-FDI relationship may be curvilinear. That is, the positive effect of experience on FDI diminishes over time. Second, this study shows that the relationship between government corruption and FDI is moderated by the decreasing effect of country-specific experience in the dynamic context of an organizational learning process. This study puts forward a contingent model to understand the effect of government corruption on FDI, thereby suggesting that the bifurcated corruption-FDI conclusion should be cautiously reinterpreted.

\section{AUTHOR INFORMATION}

Kyungho Kim is an assistant professor at School of Business, Ajou University. He received his DBA from Boston University. His research areas include corporate strategy, international business strategy, corporate social responsibility, and environmental sustainability. Kyungho Kim, School of Business, Ajou University, San 5, Woncheon-dong, Yeongtong-gu, Suwon, 443-749, South Korea. E-mail: kyunghokim@ajou.ac.kr

Hyunwoo Lim is an assistant professor at School of Business, Ajou University. He received his PhD in Management from University of Toronto. His research areas include marketing strategy, econometric modeling, and international marketing. Hyunwoo Lim, School of Business, Ajou University, San 5, Woncheon-dong, Yeongtonggu, Suwon, 443-749, South Korea. E-mail: hyunwoolim@ajou.ac.kr (Corresponding author)

\section{REFERENCES}

1. Alam, M. S. (1990). Some economic costs of corruption in LDCs. Journal of Development Studies, 27(1), 89-97.

2. Allison, P. D. (1984). Event history analysis: Regression for longitudinal event data. Newbury Park: Sage Publications. 
3. Anand, V., Ashforth, B. E., \& Joshi, M. (2005). Business as usual: The acceptance and perpetuation of corruption in organizations. Academy of Management Executive, 19(4), 9-23.

4. Ball, C. A., \& Tschoegl, A. E. (1982). The decision to establish a foreign bank branch or subsidiary: An application of binary classification procedures. Journal of Financial and Quantitative Analysis, 17(3), 411424.

5. Barkema, H. G., Bell, J. H. J., \& Pennings, J. M. (1996). Foreign entry, cultural barriers, and learning. Strategic Management Journal, 17(2), 151-166.

6. Barkema, H. G., \& Vermeulen, F. (1997). What differences in the cultural backgrounds of partners are detrimental for international joint ventures? Journal of International Business Studies, 28(4), 845-864.

7. Baum, C. F. (2006). An introduction to modern econometrics using stata. Stata Corp.

8. Benito, G. R. G., \& Gripsrud, G. (1992). The expansion of foreign direct investments: Discrete rational location choices or a cultural learning process? Journal of International Business Studies, 23, 461-476.

9. Boddewyn, J. J. (1988). Political aspects of MNE theory. Journal of International Business Studies, 19(3), 341-363.

10. Boddewyn, J. J., \& Brewer, T. L. (1994). International-business political behavior: New theoretical directions. Academy of Management Review, 19(1), 119-143.

11. Buckley, P. J., \& Casson, M. (1981). The optimal timing of a foreign direct investment. The Economic Journal, 91(361), 75-87.

12. Buckley, P. J., Clegg, L. J., Cross, A. R., Liu, X., Voss H., \& Zheng, P. (2007). The determinants of Chinese outward foreign direct investment. Journal of International Business Studies, 38, 49-518.

13. Business Anti-Corruption Portal. (2013). A snapshot of corruption in the Republic of Korea. Retrieved from http://www.business-anti-corruption.com/country-profiles/east-asia-the-pacific/republic-ofkorea/snapshot.aspx

14. Cameron, A. C., \& Trivedi, P. K. (2009). Microeconometrics using STATA. STATA Press.

15. Cohen, W. M., \& Levinthal, D. A. (1990). Absorptive capacity: A new perspective on learning and innovation. Administrative Science Quarterly, 35(1), 128-152.

16. Cuervo-Cazurra, A. (2006). Who cares about corruption? Journal of International Business Studies, 37(6), 807-822.

17. Cyert, R. M., \& March, J. G. (1963). A behavioral theory of the firm. Englewood Cliff, NJ: Prentice Hall.

18. Delios, A., \& Beamish, P. W. (2001). Survival and profitability: The roles of experience and intangible assets in foreign subsidiary performance. Academy of Management Journal, 44(5), 1028-1038.

19. Doh, J. P., Rodriguez, P., Uhlenbruck, K., Collins, J., \& Eden, L. (2003). Coping with corruption in foreign markets. Academy of Management Executives, 17(3), 114-127.

20. Erramilli, M. K. (1991). The experience factor in foreign market entry behavior of service firms. Journal of International Business Studies, 22(3), 479-502.

21. Heineman, B. W., \& Heimann, F. (2006). The long war against corruption. Foreign Affairs, 85(3), 75-86.

22. Henisz, W. J. (2000). The institutional environment for multinational investment. Journal of Law, Economics and organization, 16(2), 334-364.

23. Hennart, J. F., \& Park, Y. R. (1994). Location, governance, and strategic determinants of Japanese manufacturing investment in the United States. Strategic Management Journal, 15(6), 419-436.

24. Jain, A. K. (2001). Corruption: A review. Journal of Economic Surveys, 15(1), 71-121.

25. Johanson, J., \& Vahlne, J. E. (1977). The internationalization process of the firm: A model of knowledge development and increasing foreign market commitment. Journal of International Business Studies, 8, 2332.

26. Kim, Y. S. (2009, July 16). Corruption in Korea. Korea Times. Retrieved from https://www.koreatimes.co. kr/www/news/opinon/2009/07/137_48563.html

27. Kogut, B. (1983). Foreign direct investment as a sequential process. In C. P. Kindleberger \& D. Andretsch (eds.), The multinational corporations in the 1980s (pp. 38-56). Cambridge, MA: MIT Press.

28. Kogut, B. (1991). Joint ventures and the option to expand and acquire. Management Science, 37(1), 19-33.

29. Kostova, T., \& Zaheer, S. (1999). Organizational legitimacy under conditions of complexity: The case of the multinational enterprise. Academy of Management Review, 24(1), 64-81.

30. Levinthal, D. A., \& March, J. G. (1993). The myopia of learning. Strategic Management Journal, 14(winter), 95-112.

31. Levitt, B. B., \& March, J. G. (1988). Organizational learning. Annual Review of Sociology, 14, 319-340. 
32. Li, J. (1995). Foreign entry and survival: Effects of strategic choices on performance in international markets. Strategic Management Journal, 16(5), 333-351.

33. Luo, Y. (1998). Timing of investment and international expansion performance in China. Journal of International Business Studies, 29(2), 391-408.

34. Luo, Y., \& Peng, M. W. (1999). Learning to compete in a transition economy: Experience, environment, and performance. Journal of International Business Studies, 30(2), 269-296.

35. Mauro, P. (1995). Corruption and growth. Quarterly Journal of Economics, 110(3), 681-712.

36. Mayer, T., \& Zignago, S. (2011). Notes on CEPII's distances measures: The Geodist database. (CEPII Working Paper, No.2011-5).

37. Meschi, P. X. (2009). Government corruption and foreign stakes in international joint ventures in emerging economics. Asia Pacific Journal of Management, 26(2), 241-261.

38. Mitchell, W., Shaver, J. M., \& Yeung, B. (1992). Getting there in a global industry: Impacts on performance of changing international presence. Strategic Management Journal, 13(6), 419-432.

39. Mitchell, W., Shaver, J. M., \& Yeung, B. (1994). Foreign entrant survival and foreign market share: Canadian companies' experience in United States medical sector markets. Strategic Management Journal, 15(7), 555-567.

40. Mookherjee, D., \& Png, I. P. L. (1995). Corruptible law enforcers: How should they be compensated? Economic Journal, 105(428), 145-159.

41. Nelson, R., \& Winter, S. (1982). An evolutionary theory of economic change. Cambridge, MA: Harvard University Press.

42. North, D. (1990). Institutions, institutional change, and economic performance. Cambridge, UK: Cambridge University Press.

43. O'Higgins, E. (2006). Corruption, underdevelopment and extractive resource industries: Addressing the vicious cycle. Business Ethics Quarterly, 16(2), 235-254.

44. Pennings, J. M., Barkema, H., \& Douma, S. (1994). Organizational learning and diversification. Academy of Management Journal, 37(3), 608-640.

45. Rodriguez, P., Uhlensruck, K., \& Eden, L. (2005). Government corruption and the entry strategies of multinationals. Academy of Management Review, 30(2), 383-396.

46. Rodriguez, P., Siegel, D. S., Hillman. A., \& Eden, L. (2006). Three lenses on the multinational enterprise: Politics, corruption and corporate social responsibility. Journal of International Business Studies, 37(6), 733-746.

47. Shaver, J. M., Mitchell, W., \& Young, B. (1997). The effect of own-firm and other-firm experience on foreign direct investment survival in the United States, 1987-1992. Strategic Management Journal, 18, 811-824.

48. Shleifer, A., \& Vishny, R. W. (1993). Corruption. The Quarterly Journal of Economics, 108(3), 599-617.

49. Smarzynska, B., \& Wei, S.-J. (2000). Corruption and the composition of foreign direct investment: Firmlevel evidence. (Working paper No. 7969). National Bureau of Economic Research, Cambridge, MA.

50. $\quad$ Statistics Korea. (2004). Report on mining and manufacturing survey. Statistics Korea.

51. Tanzi, V. (1998). Corruption around the world: Causes, consequences, scope, and cures. (Working paper No. 98/63). International Monetary Fund, Washington, DC.

52. Teece, D. J., Pisano, G., \& Shuen, A. (1997). Dynamic capabilities and strategic management. Strategic Management Journal, 18, 509-533.

53. Tullock, G. (1996). Corruption theory and practice. Contemporary Economic Policy, 14(3), 6-13.

54. Wei, S.-J. (1997). How taxing is corruption on international investors? (NBER Working Paper, No.6030). Cambridge, MA: National Bureau of Economic Research.

55. Wei, S. J. (2000). How taxing is corruption on international investors? The Review of Economics and Statistics, 82(1), 1-11.

56. Zaheer, S. (1995). Overcoming the liability of foreignness. Academy of Management Journal, 38(2), 341363.

57. Zhao, J. H., Kim, S. H., \& Du, J. (2003). The impact of corruption and transparency on foreign direct investment: An empirical analysis. Management International Review, 43(1), 41-62.

58. Yu, C. J. (1990). The experience effect and foreign direct investment. Review of World Economics, 126(3), 561-580. 


\section{NOTES}

